\title{
The Research on Farmers' Income from Property Based on Agrarian Supply-side Structural Reform
}

\author{
Yan Minxin \\ College of Marxism, Jiangsu University, Zhenjiang, China \\ Email address: \\ 784396162@qq.com \\ To cite this article: \\ Yan Minxin. The Research on Farmers' Income from Property Based on Agrarian Supply-side Structural Reform. International Journal of \\ Agricultural Economics. Vol. 3, No. 4, 2018, pp. 89-93. doi: 10.11648/j.ijae.20180304.15
}

Received: August 14, 2018; Accepted: August 30, 2018; Published: October 13, 2018

\begin{abstract}
In the new era of building socialism with Chinese characteristics, in order to narrow the gap between the income of urban and rural residents, we must constantly improve salary income, income of profit-making and metastatic income. Meanwhile, we should actively increase the proportion of the farmers' property income in total income. According to the specific analysis of the property income of farmers in Jiangsu Province, the proportion of the income of the farmers' property income is small, the regional difference is large, and the gap between urban and rural areas is large. Land is the farmers' most important property and land revenue is an important component of farmers' income from property. Excellent rural land system can effectively protect and increase farmers' property income. Agricultural supply-side structural reform put forward by the central in 2016 emphasis to vigorously promote the reform of rural land system. Based on this, this article analyzes influences on farmers' property income from the system of rural land contract and management right, rural land expropriation system, rural homestead system and the rural collective management of construction land, and then puts forward to paths of increasing farmers' property income: deepen the reform of the rural land property rights system; comprehensively promote reform of the rural land expropriation system and the rural homestead system; promote the introduction of land for collectively-owned construction into the market.
\end{abstract}

Keywords: Farmers' Income from Property, Rural Land System, Supply-side Structural Reform

\section{Introduction}

Farmers' income from property refers to the income obtained by land circulation or expropriation, housing rent and appreciation of financial assets on the basis of the property they own, which is an important part of the income of farmers. Land is the most important resource for farmers[1], and how farmers use land to obtain property income is the key to increase property income. The reform of rural land system is one of the key points of agricultural supply-side structural reform. Therefore, based on the implementation of the strategy of rural revitalization and the deepening of agricultural supply-side reform, this paper studies the problem of farmers' income from property in China from the perspective of rural land system.

\section{Current Situation of Farmers' Income from Property in China}

Since the reform and opening-up in 1978, China's economy has been developing rapidly, and people's income and living standard have increased significantly. However, there are still considerable problems in farmers' income from property.

\subsection{Farmers' Income from Property Plays a Minor Role Among the Four Sources}

The rapid development of China's economy in recent years has promoted the annual increase of farmers' total income. At the same time, farmers' property income is also increasing year by year. However, the proportion of farmers' property income in total income is still low. For example, in Jiangsu province, even though both per capita disposable income and net property income increased compared to the previous year, net property income only accounted for 3.16 percent of total 
income in 2014. Therefore, increasing farmers' property income through multiple channels and increasing the proportion of property income in the total income of farmers is the key to promoting the farmers' income.

\subsection{There Is a Big Difference in the Area of Farmers' Property Income}

Due to geographical differences, different policies and imbalance of regional economic development, there is a gap in farmers' property income in various regions. Taking Jiangsu province as an example, in 2016, the per capita net property income of farmers in South Jiangsu, Central Jiangsu and North Jiangsu accounted for $7.43 \%, 3.0 \%$ and $2.13 \%$ of total income respectively. Obviously, in 2016, the property income of farmers in South Jiangsu and North Jiangsu was nearly 6 times different, and their proportion in total income was also 3.5 times different. The reasons for these differences include not only the gap in economic development level, but also the formulation and implementation of rural land policies by local governments.

\subsection{There Is a Large Gap in Property Income Between Urban and Rural Residents}

In recent years, the income of urban and rural residents has been increasing year by year, and the property income has been gradually increased. However, the per capita property income has also been significantly different between urban and rural residents. In Jiangsu province, the property income of urban residents is significantly higher than that of farmers. From 2013 to 2016, the net property income of urban residents was about 7 times that of farmers.

\section{The Impact of Rural Land System on Farmers' Income from Property}

Land is the foundamental to the survival of farmers. Land system is the most basic system of the country, and constitutes the foundation of production relations and all economic relations. Therefore, the rural land system has a great relationship with whether the farmers' property income can be effectively guaranteed. At present, it can be seen from the property income of farmers in Jiangsu province in recent years that there are many and serious problems in the property income of farmers in China. Then, why farmers' property income can not be guaranteed and improved all the time? We must start from the root, that is, from the perspective of rural land system to find the answer.

\subsection{The Impact of the System of Rural Land Contract and Management Right on Farmers' Property Income}

Constitution of China stipulates that urban land belongs to the state and rural land belongs to collective ownership. And relevant law also stipulates that the rural land contract adopts household contract management within the rural collective economic organization. In simple terms, as long as the household belongs to this collective economic organization, they can contract the collective land according to law and get legal protection. This legal provision combines the property in rural land with land contract right. However, the right of management does not have a specific identity and a specific object. It can be integrated with or separated from the property and contract right. The right of management of rural land can be handed over to a third party by the owner and contractor of the land.

The members of collective economic organizations contract the land, which means they have possessed the collective assets. If they give up the contract, they lose the opportunity to possess the collective assets. In law, they can also be regarded as losing their own property and income. Therefore, in order to prevent the occurrence of this situation, many areas in China have carried out the reform of stocklization of land contract and management rights. Through this kind of reform, farmers acquired the property of land assets, rather than the actual land. The reform not only protects the interests of the collective and farmers, but also promotes the increase of farmers' income from property[2].

\subsection{The Impact of Rural Land Expropriation System on Farmers' Income from Property}

Based on the needs of public interests, the state shall set procedures by administrative organs according to law to obtain the land of peasants by compulsory means and give corresponding compensation to peasants, which is called rural land expropriation. The accelerated urbanization inevitably leads to a wider and wider area of land expropriation in rural areas. In the process of expropriation, farmers' property income is inevitably damaged.

The interest relationship between local government and peasants is the key issue involved in the rural land expropriation system. Coordinating the interest relationship effectively between them can guarantee the farmers' property income reasonably. However, the situation is not optimistic from the land acquisition in China.

In our country, rural land dose not circulate in the market, so it can be controlled by the government, without the need for inspection and approval by the market. The stipulation makes compensation fees of rural land is extremely low, and far behind the current level of economic development in China, which hindered the increase of farmers' income from property. At the same time, because of the different levels of economic development in different regions of China, the compensation standard of rural land expropriation in different regions is also far different, which widens the gap of farmers' property income in different regions.

After the implementation of market economy in China, the approach of compensation and settlement for land-lost farmers changed from employment settlement to monetary settlement, and the compensation cost is estimated according to the multiple of agricultural annual output value. However, in fact, the living cost of peasants after losing their land has greatly increased, so it is difficult to spend it by compensation during the period of searching for a new way of life. This 
situation reduces farmers' income and the quality of life, and reduces or even disappears the property income that could be obtained by land, which is also the main reason for the low proportion of farmers' property income in total income.

\subsection{The Impact of Rural Homestead System on Farmers' Income from Property}

In the land system of our country, the ownership of the rural homestead belongs to the collective, and the right of use belongs to the peasant household. Since the implementation of cooperatives in China, only members of collective economic organizations can get homesteads, and those outside the organization are not qualified to apply and obtain. To some extent, this provision legally guarantees farmers' income from property.

At present, a large number of rural homesteads enter the market. In the vast rural areas, some farmers build more floors to the original houses on the homestead, which are used to rent to the migrant workers. This move increases the property income of farmers. In addition, some farmers who have taken root in cities and towns rent out their homesteads to other farmers to build houses, which adds an extra property income for the leaseholders. For the tenants, they can also get property income by means of renting or letting the obtained homesteads. Of course, although these measures have increased the farmers' income from property to some extent, the law does not stipulate that the homestead can be rented, transferred and traded, so there is no legal protection, which has led to a variety of disputes and conflicts.

\subsection{The Impact of the Rural Collective Management of Construction Land on Farmers' Income from Property}

The land used for collective construction in rural areas refers to the land used by township enterprises for construction, which is idle after the enterprises close down or move to the development zones. According to the spirit of relevant policies and the plan, the rural collective operating construction land is allowed to enter the market and the transaction is conducted in accordance with the principle of "the same land, the same price", so as to activate this part of idle land and add some assets to the rural collective economy[3]. It also creates different sources of farmers' property income.

The industrialization and urbanization on collective construction land actually created a benefit distribution mechanism different from the current government-led mode of land expropriation and urbanization[4]. The differential benefits created by non-agricultural use of rural collective construction land will be retained within the village. And because the collective keeps the ownership of collective land, they can acquire land differential income forever, which further promotes the increase of farmers' property income and is conducive to stimulating farmers' consumption.

Of course, there are some problems in China's collective construction land system at present. Firstly, the use of rural collective construction land is in a state outside the law, and farmers' property income lacks legal protection. Secondly, the rural collective construction land is outside of the urban and rural planning, which to some extent restrains the growth of its economic benefits and reduces the farmers' property income. Thirdly, the industries that use collective construction land mostly are extensive type, which make farmers' income from property cannot get actual and more substantial increase.

\section{Paths of Increasing Farmers' Property Income Based on Rural Land System}

The central economic work conference held in mid-december 2016 proposed to open up a wide range of ways for farmers to increase their income and become rich. Property income from land is an important part of farmers' property income. Increasing land property income is the key to promoting farmers' property income growth. Therefore, to realize the increase of farmers' income from property, the government must vigorously implement the strategy of rural revitalization, further promote the supply-side structural reform of agriculture and deepen the reform of rural land system.

\subsection{Deepen the Reform of the Rural Land Property Rights System}

Some scholars in the academic circle believe that the poverty of Chinese farmers is widespread, which is materially poor on the surface, but actually is the poverty of rights. The loophole of rural land property right system leads directly to the loss of farmers' land interests in the process of land expropriation. Therefore, the government must deepen the reform of rural property rights system and clarify the ownership of rural collective assets[5]. At the same time, on the basis of adhering to the collective ownership of land and stabilizing the contracted rights of farmers, the circulation of management rights is promoted in accordance with the principle of market economy, and farmers are endowed with clearer and more adequate property rights such as ownership of agricultural land, right of possession, right of use and right of distribution to ensure their dominant position.

To increase farmers' income from property and protect their land property rights and interests, the government must first define and clarify who is the main body of land property right? The realization of the personalization of rural land property right is the key to the reform of rural land system in the supply-side structural reform. First, in rural land, the relationship of the property rights among collective construction land, contracted land and private plots should be clearly defined in accordance with national laws and regulations. Second, the boundary of property rights between national public land interests and farmers' land interests should be clearly defined. Thirdly, rural homestead and contracted land should be managed by classification. Local governments should do a good job in the confirmation, registration and certification of all kinds of land. Fourthly, it is necessary to reasonably define the farmers' right of ownership, 
right of use, right of profit and right of disposal of land[6]. Local governments must ensure that farmers are the subject of land property rights, and effectively protect farmers' interests based on land. In the process of developing and expropriating rural land, local governments should also perform the function of supervision, so as to avoid infringement of farmers' land interests. At the same time, it is worth noting that in order to realize the personification of rural land property rights, it is necessary to clarify farmers' rights of shares and earnings to rural land, but it does not mean the privatization of land.

\subsection{Comprehensively Promote Reform of the Rural Land Expropriation System and the Rural Homestead System}

In the process of land expropriation in rural areas, problems of land requisition procedure and guarantee mechanism are prominent. Therefore, first of all, it is necessary to strictly define the scope of land used for public interests, distinguish public welfare land and operational land, and avoid compulsory and administrative land expropriation by local governments[7]. Secondly, it is necessary to standardize and optimize land expropriation procedures, make public the expropriation information, define the compensation standard of farmers by the price of land, improve the mode of compensation and resettlement, and improve the coordination mechanism of contradiction. Finally, local governments should improve the safeguard mechanism for the land-expropriated farmers, and ensure the housing, employment and pension problems of land-expropriated farmers. In addition, for farmers' homestead, it is necessary to guarantee their usufructuary rights and carry out the pilot work actively. And for farmers' housing property right, it is necessary to mortgage, guarantee and transfer steadily, so as to promote farmers to increase their property income through multiple channels.

Among them, it is extremely important to consummate and innovate the compensation system of rural land expropriation. At present, the core of rural land expropriation system reform lies in the unreasonable compensation for land expropriation in China. In the process of land expropriation, the interests of farmers have not been effectively protected. Therefore, above all, it is necessary to raise farmers' compensation standard of land requisition. Of course, not all regions in China should use unified compensation standards, but on the basis of the unified minimum standard for requisition compensation formulated by the central government, local governments should formulate detailed compensation standards in line with local conditions, so as to better guarantee farmers' property income. Second, in the process of land expropriation, local governments can entrust a third party to make market valuations of requisition land, and then, the potential and value of the land in the future will also be included in the valuation range. In this way, farmers are able to obtain land value-added revenue from the new urbanization construction, and then farmers' income from property can be raised. Finally, it is particularly significant to regulate the procedure of land requisition, which is necessary for open and democratic procedure of land requisition. In the process of land expropriation, the local government must be through democratic consultation and collective vote to make decision, also can undertake innovation in view of the payments of land requisition compensation. For example, the local government can pilot with proportional distribution in combination with the rest on the premise of voluntary participation in collective assets investment or plan of rural endowment insurance, so as to keep and add the value of peasants' land requisition compensation, and then guarantee and increase farmers' property income.

\subsection{Promote the Introduction of Land for Collectively-Owned Construction into the Market}

In our country, people often call rural collective construction land invisible trade market. In recent years, urbanization in various regions in China have been accelerated. During this period, the hidden nature of rural collective construction land, asset has gradually emerged. These collective construction lands are often mortgaged, leased or transferred. However, due to the lack of legal protection and unified management of the market, there are prominent problems such as unclear ownership of land and unreasonable protection of farmers' rights and interests. Therefore, in order to let rural collective construction land enter the market legally and activate rural land assets, local governments must carry out the reform to promote the development of rural collective economy, so as to better protect farmers' rights and interests and then improve farmers' income from property. For example, the rural collective construction land can be traded in a fair and just way like state-owned construction land through unified online public bidding, and then, the growth of farmers' property income can be promoted.

\section{Conclusion}

The report of the 19th National Congress of the Communist Party of China pointed out that to implement the strategy of rural revitalization, we need to deepen the reform of the rural land system and improve the separation system of rural ownership rights, contract rights and management rights for contracted land. We will deepen the reform of the rural collective property rights system, protect farmers' property rights and interests, and strengthen the collective economy. Land is the root of farmers, and a considerable part of their property income comes from land. The reform of rural land system is crucial to the protection of farmers' rights and interests. Therefore, we should adhere to the basic principle of farmers' principal status, deepen the supply-side structural reform of agriculture, deepen the reform of rural land property rights system and land requisition system, and promote the entry of land for collective commercial construction into the market, so as to guarantee and improve farmers' income from property reasonably and enable them to enjoy the fruits of common prosperity. 


\section{References}

[1] L. F. Jin. Growth Bottleneck and Policy Correction of the Property Income of Farmers in Jiangsu Province [J]. Journal of Nantong University(Social Sciences Edition), Vol. 34, No. 3, 2018, pp. 143.

[2] J. Zhang. Reform of Rural Property Rights System and Increase of Farmers' Property Income [J]. Rural Economy, No. 11, 2014, pp. 4.

[3] X. Z. Kong. The Basic Connotation and Policy Suggestions on the Structural Reform of Agricultural Supply Side [J]. Reform, No. 2, 2016, pp. 107.

[4] S. Y. Liu. Face up to China's Land Problems [M]. Beijing, China development press, 2014, pp. 36.

[5] J. Y. Xu. Some Issues on Promoting Agricultural Supply-side Structural Reform [J]. Journal of Jishou University(Social Sciences), Vol. 38, No. 3, 2017, pp. 70.

[6] C. H. Zhang. Obstacles and Solutions to the Increase of Rural Land Property Income [J]. Rural Economy, No. 10, 2016, pp. 108.

[7] J. Y. Xu. The Evolution of Rural Land System Reform in China [J]. Huxiang Forum, Vol. 30, No. 2, 2017, pp. 82.

\section{Biography}

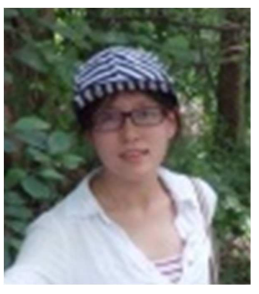

Yan Minxin (1994- ), Current master student, Research direction: Study on the sinicization of Marxism, Graduation thesis: The Research on Influence and Countermeasures of Land Expropriation on Farmers' Property Income, Have published three papers, Have hosted one national project and two school projects, Currently Participated in the key project of national social science fund "The research on the influencing factors and guarantee mechanism of growth of farmers' property income in the new normal". 